This is a pre-copyedited, author-produced version of an article accepted for publication in Journal of Hindu Studies, following peer review. https://doi.org/10.1093/jhs/hiz017

Accepted version downloaded from SOAS Research Online: http://eprints.soas.ac.uk/31947

\title{
Playing the Spinal Chord: Tantric Musicology and Bengali Songs in the Nineteenth Century
}

\author{
Richard David Williams \\ SOAS University of London \\ richard.williams@soas.ac.uk
}

\begin{abstract}
Across the nineteenth century, Bengali songbook editors applied musicological theory to their tantric religious practices. Responding to the new possibilities of musical publishing, these editors developed innovative techniques of relating the body to music by tying together tantric tropes with music theory and performance practice. Theories about the affective potential and poetic connotations of rāgas were brought into conversation with understandings of the yogic body, cakras, and the visualization of goddesses. These different theories, stemming from aesthetics and yogic philosophy, were put into effect through lyrical composition and the ways in which songs were set to music and edited for printed anthologies. This article considers different examples of tantric musical editorial, and explores how esoteric knowledge was applied in innovative ways through the medium of printed musical literature.
\end{abstract}

Keywords: tantra; nineteenth century; songs; śākta religion; North Indian music; Bengali literature.

\section{Introduction}

In the late nineteenth century, Māhtābcānd (1825-1879), the Raja of Burdwan, oversaw the publication of a number of religious songbooks designed for Bengali śāktas, devotees of the Goddess. ${ }^{i}$ His own father, Tejascānd, was the disciple of the famous śākta poet Kamalākānta Bhaț̣āārya (McDermott 2001a, 84-127, 204-231; 2001b), and Māhtābcānd arranged for 269 of Kāmalākānta's padas to be published. He identified lyrics from the poet's notebooks and then consulted with musicians to find the appropriate musical settings for the texts, resulting in $r \bar{a} g a$ and $t \bar{a} l a$ prescriptions that appeared in the printed version (Bandyopādhyāy 1857). Māhtābcānd wrote and published his own poems too, and following his death in 1879, several collections of his remaining lyrics were also prepared and printed posthumously. The editor charged with this task, Aghornāth Tattvanidhi, described these songs as musical compositions (saingìt racnā) and explained Māhtābcānd's creative process to his readers: the Raja would write a poem and then give it to his court musicians, "learned singers well-versed in melody and rhythm” (tān-lāájĩna aijñagāýak) to sing (Māhtābcāndra 1880, i):

thus, all this music was specially tested (biśeșrūpe parīkșit) and entered through the ear-holes with the notes and moistened the inner ear of those who could appreciate it, their eyes streaming with tears

A year later, in the preface to another collection of Māhtābcānd's verses, Aghornāth reassured his readers that he had repeated this process for some of the Raja's unfinished songs, which had been perfected for publication by consulting people with musical expertise (saingitt-rasajñ sāmājik-gaṇ) (Māhtābcānd 1881, i).

These remarks gesture to a larger set of interconnected conversations that were taking place across the second half of the nineteenth century around the relationship between music and religious experience, and how the visual form of the song in print could be fine-tuned. Aghornāth's comments resonate with other contemporary songbook editors: the language of testing or experimenting with the musical setting, and of rendering a lyric poem (pada) into a musical work (saingīt). This editorial consisted of consulting with musicians or musical connoisseurs, discussing the appropriate $r \bar{a} g a$ and rhythms for the songs, and then considering how best to arrange the text on the page for unknown readers, singers, and listeners. On the one hand, this was a question of new printing practices - since these editors were working at a time when the songbook market was flourishing in Bengal—and musical aesthetics on the other. However, in the context of śákta worship, these editors were especially attentive to the 
place of sound and music in the body of the devotee. Aghornāth's comment on the moistening or softening ( $\bar{a}$ rdra kariýa $)$ of the inner ear (antahkaraṇ) gestures to the significance of embodied listening — the somatic sensation of feeling sounds within the body—in śākta music-making.

Editors like Aghornāth can be situated in a longer history of śākta music and literature in Bengal, especially the larger oeuvre of śākta-padāvalī, dedicated to the goddesses Kālī and Umā. Rachel Fell McDermott (2001a) has traced the proliferation of these lyrics and poems across the eighteenth and nineteenth centuries; she notes that while most histories of this literature are framed by the figures of Rāmprasād Sen (c.1718-1775, see also McLean 1986) and Kamalākānta Bhațāāārya (1843-1908), there were many other poets and singers composing works over the intervening decades. McDermott demonstrates how these composers' works ranged in tone, varied in how they were received and framed by later $s \bar{a} k t a s$, and appealed to different kinds of religious practice, from devotional singing to tantric sädhana. The composers themselves came from a variety of social backgrounds, from aristocratic zamindars like Māhtābcānd, to court poets and dewāns, to public entertainers and professional musicians. Composers with musical training came from both low and high castes, and both rural and urban contexts (2001a, 132-5). From the 1850s, religious and social reform trends influenced ideas relating to culture and taste, which led to a shift away from śákta-padāvalī composition in favour of vaiṣnava and secular literature. At the same time, over the latter half of the nineteenth century, editors like Aghornāth printed and curated śäkta lyrics, culminating in substantial song collections, such as Harimohan Mukhopadhyāy's Sañīt Sār Sañgraha (1899).

These collections provided a significant resource for worship and the practice of sacred music. As songbooks, they might also be read as one facet of an explosion in Bengali musical publishing, that escalated over the second half of the nineteenth century (Williams 2016). This article considers these two dimensions of the song collection-as a śákta tool of worship and as an exercise in musical editorial—and examines how Bengali songbooks drew connections between the discipline of music theory and the bodily techniques of tantric Śāktism. These connections were built upon a shared metaphysical foundation, especially the assumption that the embodied self can be manipulated through sound. While there was a longer history of different engagements with this concept in Bengal (Sharif 1967; White 2003; Hayes 2003; Das 1992), the songbooks I focus on here reflect their distinctively nineteenth-century intellectual horizons, when the colonial-era book trade encouraged new possibilities for curating and prescribing religious music.

From an archival and methodological perspective, engaging meaningfully with songbooks poses several challenges. While they might be seen as material inscriptions of sound, they do not lend themselves easily to resounding. In other words, we know these books are finely-tuned musical objects, but we cannot hear the music embedded in their pages. As a result, researchers are more likely to read the lyrics silently as poems, muting the significance of the $r \overline{a g} a$ and $t \bar{a} l a$ settings that were evidently meaningful to their singers and editors. However, the silence of the printed page was less of a concern to men like Aghornāth, who went to great lengths to consult musicians and boasted to their readers that they had identified the most appropriate settings, assuming that these reader-singers would be able to reap the fruits of their labours from off the silent page.

Bengali musicologists began experimenting with printed notation for song texts over the 1870s (Williams 2016, 477, 486), but notation never became the norm: the majority of songbook editors were content to provide a suggested $r \bar{a} g a$ and $t \bar{a} l a$, often as a heading above the lyric. From the name of the $r \overline{a g} a$, a trained singer would know how to improvise a composition, following rules concerning which degrees of the scale to include and which melodic shapes or motifs to include. These books are therefore inclined towards ensembles of worshippers, at least some of whom would have some musical expertise. Some of the settings provided in the nineteenth-century books pose specific challenges: some $r \bar{a} g a$ settings are unusual or obscure, so did the editors always expect their readers to be able to identify them and sing appropriately? McDermott notes the gradual rise in popularity of "Rāmprasād's tune" (rāmprasādì sur) across collections: this is a folk-style tune, akin to Bāul gān, in 
Bilāval rāga and ekatāla (McDermott 2001a, 178, 375n12). This trend might indicate at least some demand for a more accessible musical option, where the reader would need to remember one tune rather than how to correctly elaborate a $r \bar{g} g a$ through improvisation.

At the same time, marking a text as a musical work meant more than prescribing a performance: crucially, each $r \overline{a g} a$ has its own set of connotations and affective values that informed the meaning of the lyrics and could nuance how they were interpreted and realised through sung worship. In this article, I particularly examine how the songbook editors were conscious of the place of sound in the yogic body and the religious significance of the embodied sense of sound, and how the extra-musical meanings of a rāga were brought to bear on the tantric visualisation (dhyāna) of deities through hymns. I place these ideas in context, by first considering the place of the yogic body in musical thought. I then examine three songbooks as case studies of how Bengali śăktas layered poetic texts with musical performance and concepts to prescribe specific reading and resounding practices, in order to enhance the aesthetic value, affective and ritual power of the lyrics. This article does not presume to offer concrete findings, but rather to explore a set of readings and interpretative possibilities posed by engaging musicology in the study of religious lyrics. Given that the song collectors in this essay positioned themselves between tantric piety and the music book market, how can the reader today attempt to "listen between the lines" of a song text?

\section{Music in the Body}

When Aghornāth Tattvanidhi described how he had consulted music connoisseurs on the preparation of the song texts for printing, he could have been referring to different kinds of expertise: the applied knowledge of the court singer ( $g \bar{a} y \dot{a} a k)$ but also of the informed and appreciative listener (bhäbukgan). Over the nineteenth century, a new class of bhadralok music enthusiasts invested themselves in the theory and practice of music, resulting in the proliferation of books in Bengali on musicology (Williams 2016). These authors re-worked the older discipline of music theory and aesthetics (often termed sanigìta-śāstra or 'ilm-i$m \bar{u} s \bar{q} q \bar{l}$ ) that had been cultivated by early-modern intellectuals working in Sanskrit, Persian and vernacular languages (Rowell 1992; Te Nijenhuis 1977; Te Nijenhuis and Delvoye 2010; Bhatkhande 1984). It was an established convention among these musicologists to refer to a yogic understanding of the body: that is, that the body is constituted of multiple sheaths, and that the yogic body contains multiple pathways (nādū) of the flow of vital energy (prāna), named $\bar{i} d \bar{a}$, sușumnā, and pingalā (Flood 2005; Mallinson and Singleton 2017, 171-186). Often, the music treatises would explain how these three pathways intersect at seven (or so) cakras, and how each cakra could be visualized as a lotus with specific properties, each bearing a seed syllable ( $b \overrightarrow{i j} a$ ) pertaining to a mantra and a cosmogram (yantra). A typical scheme for the positioning of cakras in the body includes the sahasrâra (located at the crown of the skull), the ājña (third eye), viśuddha (throat), anāhata (heart), manipüra (below the navel), svādhișthāna (the site of sexual energy), and the mūlädhāra (perineum). This modelling of the human body gained traction in musical scholarship particularly in the wake of the thirteenth-century Sañgittaratnākara of Sārngadeva, which included a discussion of human physiology, the Pindotpatti prakarana. This section examined the body three ways: as a cosmic manifestation of Brahman, then from an embryological perspective, and also through the principles of Haṭhayoga (Shringy 1978, 85-103; Sharma 1995). Śārngadeva elaborated the structure of the cakras and noted that four (anāhata, viśuddhi, lalanāa, and sahasrapatra) were crucial for proficiency in music: "The embodied soul cannot in any way accomplish anything (worthwhile) in the (field of) musical arts by concentrating on any other petals” (Shringy 1978: 98). He also referred to the passage of the serpent Kuṇulinin — defined here as the brahmaśakti-from her coiled position in the (mūl)ādhāra cakra up the spine to the aperture of Brahman (brahmarandhra) (Kitada 2012, 281-4). In his analysis of this section, Kitada (2012) has demonstrated that even within the Haṭhayoga material there are various layers and multiple sources stitched together; as a result, this section does not represent a coherent system for a yogic practice, so much as an attempt to further intellectualise ideas about music (c.f. Lath 1995). 
Sārngadeva turned to these different materials in an attempt to consider the production of sound (nādotpatti) within the human body. He engaged the older principle that the yogic body was a sonic body, both in the sense that it was inherently resonating from within (itself a musical instrument, the śarīravina â), and from the perspective that all matteras derived from the five elements (mahäbhütas) — mediated cosmic sound (Sharma 1995; Lath 1995; Katz 2000). These principles had been elaborated upon across many different intellectual traditions (Wilke and Moebus 2011). A variety of sonic practices, including the delineation of ten-fold divisions of Resonance $(r \bar{a} v a)$, are well attested in different forms across medieval Śaiva tantric texts (Vasudeva 2004, 273-280), and appear in relation to Hathayoga as early as the Amrtadsiddhi (c. eleventh century), which describes the sounds heard in the different stages of yogic awakening. The fifteenth-century Hathapradīpika elaborated a practice of "concentration on the inner sound" (nädānusandhāna), "which is approved even for those fools who are incapable of realizing the truth" (4.65 in Mallinson and Singleton 2017, 353). In this context, sound could be used as a focusing mechanism, to drown out sensory distractions (4: 90-91, 96 in Mallinson and Singleton 2017, 354; c.f. 357):

\begin{abstract}
Just as a bee drinking nectar pays no attention to the perfume, so a mind attached to sound does not desire the objects of the senses. The mind, a rutting elephant wandering about in the garden of sense objects, can be brought under control by this sharp goad of sound... By being oxidized in the Sulphur of sound, the mercury of the mind is bound and its unsteadiness eradicated, [and] it wanders in the space called "supportless".
\end{abstract}

Many ascetic traditions directed practitioners to listen for the unstruck (anāhata) sound, which could be enumerated as a series of sonic stages, signposting the progress of the disciplined mind (e.g. Ganapathy 2013, 728). Sārngadeva incorporated aspects of these systems into musicology, ultimately developing the concept of the highest reality as a sonic brahman (nädabrahman) (Wilke and Moebus 2011, 836-45).

In the nineteenth century, these ideas resurfaced and were promulgated in Bengal through the work of Rādhāmohan Sen Dās, who wrote the Sañgitatarañga ("Wave of Music," 1818), the first Bengali music treatise to be published. ${ }^{\text {ii }}$ Translating and summarising older Sanskrit and Persian texts, he followed Śărngadeva in his opening cosmology, explaining how existence emanated from the primordial reverberation within the formless and silent void (śünya). The foundational elements stemmed from that reverberation, and by manipulating the components of sound through music, the musician had the ability to harness and control his environment (Dās 1818, 6):

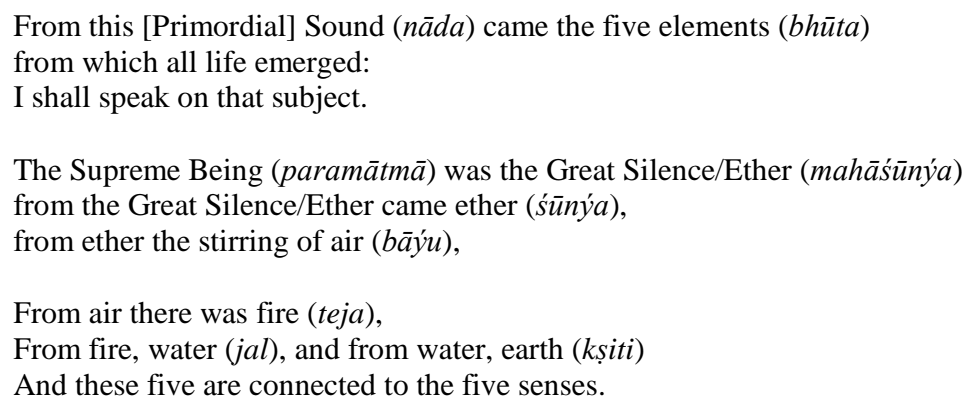

Rādhāmohan qualified this macrocosmic perspective on the derivation of nature from $n \bar{a} d a$ further: seven entities also emanated from $n \bar{a} d a$, which, he explained to his readers, the master-musicians (kalāvants) knew as svaras (notes) (Dās 1818, 8). iii These notes were resounding in the microcosm of the human body, running along the three nādiss, which Rādhāmohan illustrated for his readers with a schematic diagram (Dās 1818, 9-10).

The primordial power of these notes could be activated when they were arranged through $r \bar{a} g a$. In music treatises, rāga could be explored in two different modes. On a formal level, the $r \overline{a g} a$ provided a grammar for improvised composition, outlining which degrees of the scale to include, and which melodic formulae or motifs to include to articulate the rāga's distinctive character. However, this character could also be discussed through non-musical 
features, such as the rāga's emotional connotations, its association to different seasons and times of day, as well as its iconographic visualisation (dhyāna). These meanings embedded in the $r \bar{g} g a$ became prominent in musical scholarship over the seventeenth and eighteenth centuries, which examined the affective and material powers of $r \overline{a g} a$ music, sometimes termed, "The Fifth Veda": music could melt stones, summon snakes out of hell, tame wild beasts, and control the weather..$^{\text {iv }}$ Drawing upon the powers of the $r \overline{a g} a$, it was understood that musicians could manipulate the materiality of the human constitution, influencing the emotions and physical disposition of their listeners. These concepts were interpreted through different intellectual systems, and musicologists threaded together Indic understandings of $r \bar{a} g a$ and Perso-Arabic Unani medicine, in order to explain the physiological and humoral basis for musical experience (Brown 2003, 177-225; Schofield 2018). By the mid-nineteenth century, musicologists preserved but also qualified or rationalised these affective powers (Imam 1959, 8):

\begin{abstract}
The Bhairon [Raga] could move an oil-press; the Malkaus could produce light in darkness, i.e., the sun and the moon would rise out of time; the Hindal could make the flowers blossom and also make the swings move; the Megh could bring about a downpour: and the Deepak could produce a conflagration, and hence singing of this Raga was banned and its place given to the Khat Raga. The Shree Raga could cause a storm. This is how our forebears described the effects of various Ragas. In fact the above Ragas were able to produce the prescribed power in those days. But now these effects have totally disappeared. Instances of Ragas captivating the minds of the listeners or making them weep, etc., are to be found even today.
\end{abstract}

In this particular instance, the Urdu scholar Karam Imam (writing c.1858) appeared to be negotiating between the imaginary of the tradition, which enriched the connoisseur's experience of the music, and a quasi-disenchanted worldview. His compromise was to suggest that the world had changed, and the magic of music was no longer a given.

While we cannot know for certain how many śákta composers or editors had read the Sanigitataranga, Rādhāmohan's book set the tone for Bengali musical publishing, explained the relevance of the yogic body to music, and made earlier systems accessible to new audiences. He underlined the interdisciplinary nature of musicology, listing the intellectual genres that he had surveyed in the course of writing his treatise (Dās 1818, 7):

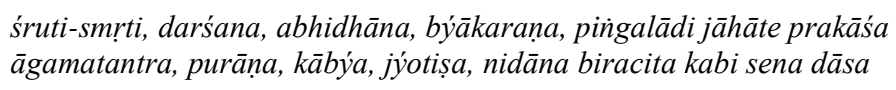

Shedding light on Scriptures, Philosophy, Lexicography, Grammar, Prosody and so forth, Āgamic tantra, the Purānas, Poetry, Astrology, and Etiology—the poet Sen Das has composed on these.

While Rādhāmohan listed Āgamic tantra as but one ingredient in the complex of musicology, for certain readers, the intellectual connections between music and tantra could be brought to the fore and deployed in devotional practice. The Sangitataranga, which was republished in 1849 and then 1903, became a significant point of reference for later scholars who did not have advanced training in musicological Sanskrit. Over that period, editors and compilers of song collections operated as entrepreneurs, exploring the markets and technological opportunities of print. Song book editors were innovators and experimented with fonts, different notation styles, and various modes of inscription to prescribe different reading and performance practices for their consumers. In the following section I will consider three especially illuminating examples of how musical editorial techniques were applied to śäkta worship.

\title{
Waves of Musical Bliss
}

In 1848, Mādhabcandra Datta Caudhurī published a songbook titled Sañgītānanda Laharī (Waves of Musical Bliss, 1848), and proudly framed his endeavour as fusing together music, literature, and religious devotion. In his preface, he recounted how he had become enamoured with the devotional poems of the litterateur Rāmacandra Bhatțāaārya, and wished to make 
them available to both a learned readership, and a more popular, listening audience (Caudhurī 1848, ii):

\begin{abstract}
With the kind permission of Mr Bhațtacāryā I have tied together in lyrical form his songs and poetic compositions and so forth: seeing and relishing that string of clouds, the thrilled peacock of the mind remains dancing forever more [...] Afterwards, I combined them with rāgas, rāginis and tālas, consulting with instrumentalists and singers. After much toil and with the expectation that all these songs should be in an accessible format for this nation's society, in that spirit I conferred upon it the name Waves of Musical Bliss, and braved myself at once to dispatch it to the printing press.
\end{abstract}

Neither Mādhabcandra nor Rāmacandra are lesser-known figures in this arena, and I have struggled to find additional information about them. However, this preface does capture Mādhabcandra's excitement, deploying familiar literary tropes ("the thrilled peacock of the mind” [which dances before the monsoon clouds], citta śikhī sukhī), and his emotional investment in the production process ("braved myself at once to dispatch it to the printing press”, mūdrā jantrālaýe preșaṇa karaṇe sahasā sāhasī hailām). Mādhabcandra combined two long works of verse, a gìtầvalī (song series) dedicated to the goddess Durgā (as Śrī Bhavānī), and a padāvali (verse series) on Kṛ̣ṇa’s Rāslīlā.

Mādhabcandra formatted the lyrics with clear rāg $a$ and tāla headings, dānṛi strokes to mark the different verses and commas to separate clauses, and a highlighted refrain (dhruba). We should recall that in a mid-nineteenth century context, none of these interventions was straightforward or obvious. Other song book compilers followed the precedent of manuscript culture, filling the page with lines of lyrics that ran on from one another, i.e. scriptio continua, without any annotation or punctuation besides the dānrri strokes. Separating the lyrics from one another, then isolating each line, and then applying Western commas, had a crisp, visual impact but also guided readers and singers in their use of the book in a more clearly defined way than a manuscript handbook would have done. Notably, like Aghornāth Tattvanidhi in the first example in this article's introduction, the rāg $a$ and tāla settings had been added to otherwise unmarked poetic texts; Mādhabcandra did not consult with the poet in this process but conferred with an independent group of musicians and singers to determine the prescriptions. This editorial initiative, translating a literary work into a musical one, was a more complicated exercise than documenting the settings as sung in performance.

Providing musical structures for śâkta poems entailed a series of decisions: which rāgas and tălas were appropriate? How should the melodic texture shape the way readers, singers, audiences, and devotees responded to the sung poem? Some of the rāgas selected for the poems are well known—such as Bhairav, Bhairavī, Ṭorīi, Lalit, Yaman, Hamīr, and Behāg — and others are represented through a series of variants: for example, Surat is represented along with Surat Sārang and Surat Jayajayantī, and there are multiple rāgas from the Kānora (i.e. Kānaḍā) family. To take one example, Mādhabcandra presents a song dedicated to Kālī as the serpent Kunḍālinī, imploring her to draw herself up his spinal column, implicitly to unfold the cakras in sequence, and liberate the soul from worldly existence (Caudhurī 1848, 8):

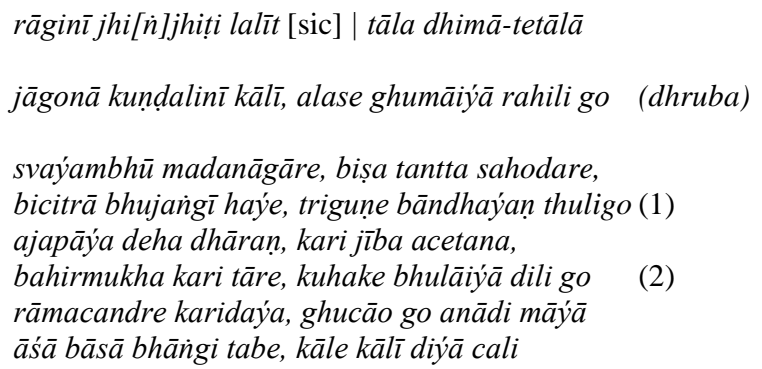

rāgin̄̄ Jhinjhit-Lalit | tāla dhimā-tetālā

Will you not wake up, Kuṇḍalin̄̄ Kālī? Will you keep on sleeping so lazily? (Refrain) 
Treasury of desire, self-born, you are like a thread of poison,

You are the spectacular serpent: grind down the limits of threefold existence. ${ }^{\mathrm{v}}$ (1)

Assuming an immortal body, make my soul senseless,

Liberate this mind-fixed on the superficial—make me forget these delusions. (2)

Have mercy on Rāmacandra, dispel this primordial illusion,

Then, my hopes and desires shattered, speed me unto death, oh Kālī! (3)

The dānrri strokes and commas shape the reading of the lyric; the commas in particular suggest the divisions of each phrase, and mark where the singer might repeat half-lines. Somewhat unusually, the poet did not end his third verse with the -ligo rhyme scheme: the audience would have to wait for the final repetition of the refrain to have the satisfaction of the closing "rahili go". Reading the lyric off the page, the singer would decide how and when to repeat the dhruba. The lyric balances elevated praise with an intimate familiarity, speaking to the goddess through her epithets and concentrating on the metaphysical trap of existence, while the recurring dhruba is personal and plaintive, calling up the dozing goddess from her reverie.

Mādhabcandra's consultant musicians prescribed dhìma-tetālā for this song. This would be slow, drawn out tempo, particularly suited for the tabla. This choice of $t \bar{a} l a$ might suggest the sluggishness of the serpent, who needs to be coaxed up the spine, but also gestures to the gravity of the song's theme. Ultimately, Ràmacandra is accepting his imprisonment in the world, and longs for the annihilation of the self. That said, the gravity of the slow rhythm would be qualified by the choice of rāginī: Jhinjhiț-Lalit. This is an unusual combination, and it is possible that many singers would have had to guess what Mādhabcandra really intended: possibly, musicians had the choice to sing the lyric in either Jhinjhit or Lalit; or they were expected to sing different verses in different rāginīs.

Alternatively, this prescribes a specific setting that was not widely known, perhaps to elevate the specialist, restricted quality of the song. Today, Jhinjhoti and Lalit are quite different in structure, though in nineteenth-century songbooks they are both associated with charming, pleasant compositions. This lighter quality to the setting for the song contrasts with those lyrics assigned rāgas associated with solemnity or power (below).

This songbook gestures to the range of decisions that faced devotional song collectors as they rendered written compositions into performative texts, especially when the editors did not consult with the original poets. With this particular lyric, was the choice of a slow tempo designed to underline the solemnity or the sluggishness of the divine serpent? Would readers recognise the pairing of the rāginiss, and understand that the song should be delivered as a pleasant-sounding piece, perhaps to nuance (or contrast with) the language of poison and selfannihilation? Or was this pairing intentionally obscure, designed to give the impression that this particular song collector understood something technical and mysterious?

\section{Listening to the Visualisation}

In this same period, Māhtābcānd of Burdwan was also developing lyrics for publication. As already noted, the Raja wrote and published his own works, as well as those of his father's famous guru, Kāmalakānta Bhaț̣āaārya. Māhtābcānd's editing projects continued even after his death (1879), as seen in the aforementioned work of Aghornāth Tattvanidhi. An early example of these songbooks was the Sangitabilās (Musical Pleasure, 1853), prepared for the raja by one Rāmprasād Rāy. ${ }^{\text {vi }}$ This book contained lyrics on a variety of themes; the bhakti corpus emerges in the final third of the text, including both śäkta-sañgìta and vaiṣnava gān.

Towards the centre of the text is a series of verses dedicated to the ten tantric goddesses known as the Mahāvidyās (Māhtābcānd 1853, 86-91). While this divine collective appears to have crystallised as a group in the twelfth century and had a longer history in eastern India (Shin 2018), McDermott notes how zamindar poets like Māhtābcānd became fascinated by these goddesses over the eighteenth and nineteenth centuries, and took inspiration from their iconographies in Sanskrit tantric texts when composing their Bengali 
songs (McDermott 2001a, 238-9). These iconographies related to their visualisation (dhyāna), which allowed the tantric practitioner to mentally construct an imaginary of each goddess and contemplate her qualities in meditation and ritual (Bühnemann 2000). In the Sangittabilās, we find a single hymn for each goddess, each with a different $r \bar{a} g a$ (see Table).

What was the significance of allocating these specific rāgas to the Mahāvidyās?

While we cannot know the composer or editor's intentions for certain, it is possible that when the users of the songbook saw these settings they brought the larger associations of each $r \overline{a g} a$ to bear on how they imagined each goddess and sung her visualisation into being. While the rāga refers to a melodic entity and an arrangement of notes, it is also coloured by emotional, seasonal, gendered, and iconographic associations (Leante 2009). In some cases, these qualities are relatively stable and well-established among musicians, while others are more obscure and only discussed in theoretical texts. In musical literature and painting (i.e. rāgamāla ), these associations were brought together in a visualisation, also called a dhyāna, that translated the auditory experience of the $r \bar{a} g a$ into image and text (Powers 1980).

Looking at the rāgas assigned to these ten hymns, there is no pattern in their time allocations (they cover early and late afternoon, early and late night, but in no special order), and in terms of musical structure there are no clear commonalities either. However, it is possible that the different $r \overline{a g}$ as were intended to reflect the different personalities and qualities of the Mahāvidyās: a sonic complement to the iconographic. This would suggest that the character of each goddess was defined partly through hearing the rāgas in performance, but also in appreciating their broader, extra-musical associations.

\begin{tabular}{|c|c|c|}
\hline Goddess & Rāga & Tāla \\
\hline Kālī & Gauṛsāranang & Dhimā Tetālā \\
\hline Tārā & Lum Khāmbāj & Ṭhunggrī \\
\hline Șoṛaśí & Multān̄̄ & Jalad Tetālā \\
\hline Bhubaneśvarī & Behāg & Jalad Tetālā \\
\hline Bhairavī & Bāgeśvarī & Jalad Tetālā \\
\hline Chinnamastā & Kedārā [sic] & Dhimā Tetālā \\
\hline Dhūmāvatī & Jhinjjhoṭ̂̄ & Jat \\
\hline Baglā & Khāmbāj & Dhimā Tetālā \\
\hline Mātañḡ̄ & Ṭoḍī & Ektālā \\
\hline Kamlā & Aṛānā Bāgeśvarī & Jalad Tetāla \\
\hline
\end{tabular}

In this scheme, Kālī was assigned Gaursāạang, which is generally considered energetic due to its oscillating vakra movements. ${ }^{\text {vii }}$ Its name also would have resonated with Gaur, the cultural heartland of west Bengal (Bor 1999, 70; Kaufmann 1968, 112-113). Therefore, it is possible that Gaursārang may have been selected for the principal goddess of the Mahāvidyās in order to ground her in the local environment, and to reflect her wild, charged nature (Kinsley 1997, 67-91).

Lum Khāmbāj is an uncommon hybrid, but presuming it drew on similar qualities to its parent Khāmbāj (Bor 1999, 100; Kaufmann 1968, 205-206), the rāga would underline Tārā's sensuality, further expressed by being paired with thungrī (i.e. thumrī) tāla: Khāmbāj and thumri was a common combination in the song collections of this period, especially for songs on popular and romantic themes. This is perhaps surprising: while Buddhist Tārā may be represented in terms of her charming, playful femininity, Hindu texts usually depict the goddess' unrestrained, violent dimensions. While her visual iconography represents Tārā in a similar form to Kālì, this musical rendering reflects an alternative, sweeter impression of the goddess, perhaps to highlight her approachability as the liberator of her devotees (Kinsley 1997, 92-111).

In her later representations, Soraśí (also known as Tripurā-Sundarī) was often conceived of as a prestigious, majestic figure (Kinsley 1997, 112-28), perhaps befitting the solemnity and contemplative restraint of Multānī (Kaufmann 1968, 554). In another, later scheme (below), Multānī was ascribed to the goddess Kamlā, who is also more auspicious and beautiful than the other, overtly terrible goddesses, suggesting that Multānī was deemed appropriate for the less violent deities. 
As her names suggests, Bhubaneśvarī is associated with the earth, and in dhyāna visualisations and paintings is often depicted as a smiling, boon-conferring deity (Kinsley 1997, 127-143): this depiction may correspond to the associations of Behāg as a loving, thoughtful rāga (Kaufmann 1968, 133).

It is perhaps surprising that the goddess Bhairavī was not simply assigned Bhairavī rāginī: the growing association between Bhairavī and "lighter" genres like thumrī possibly discouraged Māhtābcānd from applying it to a hymn. Bāgeśvarī (Bāgeśrī) has been described as a "distinguished and romantic" rāga (Bor 1999, 26), and these connotations seem to be well-matched to visual images of Bhairavī from nineteenth-century Bengal, which depict her as a beautiful mendicant or as a regal goddess poised upon a lotus. viii

Chinnamastā is perhaps the most explicitly disturbing of the Mahāvidyās: having decapitated herself, she wields her severed head in an outstretched hand, that drinks from a spout of blood issuing from her neck. Her worship is not especially common since many devotees find her too terrifying to approach (Kinsley 1997, 144-166). This may have informed Māhtābcānd's choice of $r a \bar{g} a$ Kedār, which was itself considered important and powerful, with the potential to heal diseases and to melt stones (Kaufmann 1968, 88).

Dhūmāvatī would potentially be a difficult goddess in this project: she is the dangerous widow, ugly and inauspicious (Kinsley 1997, 176-192). Māhtābcānd selected Jhinjhhoți, a very popular $r \overline{a g a}$. If one wanted to speculate how this would have been an appropriate choice, perhaps the rāga's perceived versatility-appropriate for light and serious genres (Bor 1999, 88; Kaufmann 1968, 224-226)—allowed it to be assigned to an otherwise unwholesome deity.

The pairing of Baglā with rāga Khāmbāj is not especially enlightening: while her beautiful yellow colour may have been appropriate for the sensuality of Khāmbāj, the rāga does not convey her potency in magic, and her authority over siddhis (1997, 193-208). By comparison, an alternative scheme in the Sädhak Sangìt (below) assigned Baglā the extremely magical Kedārā (sic. More typically Kedār). ${ }^{\text {ix }}$

Although Mātangī is associated with pollution, and therefore not an obvious candidate for the gentle qualities of Țoṛi, both goddess and rāgini are typically depicted as women with vịnās in their iconographies, and Māhtābcānd may have drawn on this coincidence to bring out the unsettling beauty of the goddess in his song (Māhtābcānd 1853, 90):

aparūpa kāmin̄i
śaśadhara ābhā jini

kalānātha śobe sirire sinhāsanāsana kare

birājitā tadupare caturbhuja dhārin̄ī

kheța kharga yugakare pāsáànkuśa dharāpare candre tāra krpākare he mātangi trinaýan̄

\footnotetext{
hideous beauty, cloud-coloured, brighter than moonlight the moon shines from your head, poised upon a throne radiant overhead, your four arms aloft pairing cudgel and scimitar, clutching snare and elephant hook have mercy on the moon, oh three-eyed Mātanigì!
}

Since the poetry challenges the reader's mundane preconceptions of beauty, and reveals the lustre of the dark, armed goddess, layering the sweetness of Todī over the violence of the iconography might have amplified the paradoxes within the lyric's imagery.

Finally, Kamlā was assigned an unusual combination, Aṛānā Bāgeśvarī: ${ }^{\mathrm{x}}$ as already noted, Bāgeśvar is a distinguished $r \bar{a} g a$, perhaps befitting this most auspicious of the Mahāvidyās, and was a component in several hybrid rāgas prescribed in śăkta songbooks (Kinsley 1997, 223-232; Kaufmann, 1968, 382; cf. Kānoṛa in Caudhuri 1848).

These readings are tentative, since it is impossible to confirm that these precise associations were known to everyone involved with the songbook's production and 
performance. However, this approach suggests that there were a number of possible considerations brought to bear on the allocations of rāgas to specific deities, including their affective, iconographic, and cultural connotations. These connotations provided a sonic colouring to the iconographies, and augmented the specifically musical approach to invoking the goddesses.

\section{Strumming open the cakras}

Māhtābcānd's formulation might have inspired alternative schemes. For example, some thirty years later Kailāscandra Simha published a set of hymns to the Mahāvidyās that also assigned specific rāgas to each deity in his Sādhak Sangìt (Worshipper's Music, 1885). He provided substantial introductions to the lyrics he had collected, and explained that "the songs are composed to support the visualisations" (gānguli dhýānābalambane racit haíýăche) (Simha 1885, 15). Kailāscandra did not assign any of the goddesses the same rāga that Māhtābcānd had chosen, although Bāgeśrī, Jhinjhhoțī, Kedār, and Multānī appear in both schemes. ${ }^{\text {xi }}$

Sädhak Sañit has a retrospective flavour, since Kailāscandra saw his work as creating a musical archive of Bengali goddess worship, and a resource for current devotees. McDermott (2001a, 135) has noted that while this literature fared well in the early half of the century, it entered a period of decline from the 1860s, as rural zamindars stopped writing these kinds of songs, and were increasingly unable to financially support their publication. Śákta songs lost their hold in the market along with other musical forms such as the kabiwālā, and $p \bar{a} \dot{n} c \bar{a} l \bar{l}$ and repertoires of $y \bar{a} t r \bar{a}$ troupes. While the religious genre suffered, the production of songbooks continued apace, and the śäkta editorial experiments with rāga and cultural associations continued to be influential. Notably, śākta gān was not always seen as an exclusive category of musical literature, and was combined with other kinds of song in later compendia (e.g. Ghoṣ 1889).

Kailāscandra explained to his readers that he was interested in "music on the subject of the Dark Goddess (i.e. Kālīi)" (śýāmābișaýak sangìt) from his childhood, but it was in his role as a sub-editorial assistant (sahkārī sampādak) within the Brahmo Samaj that he had access to a variety of books in Persian, English, and Bengali, which fuelled his imagination in terms of print. He was especially inspired by Kṛṣnānanda Vyās' gigantic song anthology, Sañgìta Rāga Kalpadruma (1842-1849) (Williams 2016, 487-488). He then began collecting śâkta songs from published and manuscript books, focussing his attention primarily on the works of Rāmprasād Sen, but also collated lyrics by seventeen named and several unidentified lyricists. He gathered encouragement, advice, and texts from many sources, and included a version of Rāmprasād Sen's Kālīkìrttan that Rabindranath Tagore had amended, assigning the verses with rāgas and tālas at his own discretion (Simha 1885, 2-3).

His attention to preserving the history of śäkta literature-in effect, fashioning a canon of songs for goddess worship—sets Kailāscandra's enterprise apart from our earlier examples, but he was also invested in approaching the divine through metaphysics and sound. In his introductory discussion of Śakti, Kailāscandra cited Herbert Spencer (1820-1903) as an example of Western scientists acknowledging Her reality (even without the insights of bhakti): "There is an Infinite and Eternal Energy from which every thing proceeds" (cited in English and Roman script in Simha 1885, 3fn). From this general principle, he then outlined the six cakras in his prose introduction, and later highlighted one of Rāmprasād's songs that described them (set in rāmprasādi sur and ektālā) (Simha 1885, 190): there, he noted in a footnote, "All of this can feel a little abstruse to music readers, so for that reason the six different cakras are described in detailed fashion in the introduction" (ei sakal sanigita pațhakadiger nikaț kiñcit durūh bodh haite pāre, ei janýa upakramaṇikāý șaț cakrabhed biśad-rūpe barnanā karā haiýāche.)

Rāga and cakras are explicitly entangled in a lyric Kailāscandra included by Maharaja Nandakumār Rāy (1705-1775). ${ }^{\text {xii }}$ In Bhuban bhulāili go Bhubab Mohinī, the body is represented as a vịna (stick-zither), which the Goddess—based at the mülädhära-plays through the other six cakras (Simha 1885, ii, 29): xiii 
bhubana bhulāili go bhubana mohin̄̄ mūlādhāre mahotpale bīnābādya binādin̄̄

śarīre śārīrīyantre sușamnādi eýa tantre gunabhede mahāmantre tina grāma sañcārin̄ī ădhāre bhairabākare șaradale śrīrāga āra maṇipurete mallāra basante hrta prakāsinin̄ biśuddha hillola sure karnātaka ājñāpure tāla māna laýa sure trisapta surabhedin̄̄ mahāmāýā mohapāse sthira āche saudāminī śrīnandakumāra kaya tattva nā niścaýa haý taba tattva gunatraýa kāniki mukhe ācchādin̄̄

You've enchanted the world, World-Bewitcher strumming Your vīnā from Your lotus, mūlādhāra. The body of Your instrument is in my body, The sușumn $\bar{a}$ and the others are its three strings. ${ }^{\text {xiv }}$ Through the diverse qualities of the great mantra You transition through the three scales (grāma).

Bhairav rāga (reverberates) in the $\bar{a} d h \bar{a} r a ~ c a k r a$, Śrī in the lotus of six petals (svādhișthāna cakra), Mallār in the manipura cakra,

She opens up Basant in the heart (anāhata cakra). In the viśuddha cakra one hears Hiṇdol rāga,

And Kānaḍa in the site of ājñā cakra.

Rhythm, measure, tone, melody-

She spreads the sound through three octaves,

A flash of lightning to those fixed in the enchantment of the great illusion.

Nandakumar says, no theory is for certain,

She conceals the philosophy of three qualities from the bird-brained. ${ }^{\mathrm{xv}}$

In the sixth line, when the goddess "transitions", the word sañcārinī refers to the musical movement between scales, and the motion of the goddess through the physical body (as mapped through the scales), but it also conveys a sense of excitement, arousal, or stirring, as this motion unlocks the cakras of the body. The word prakásinin ("She opens up Basant") refers to the same process: the primary sense is of the Goddess revealing and disclosing (both the cakra and the rāga itself) but also of blossoming, an appropriate image both for the cakra (imagined as a lotus), and for the $r \bar{g} g a$ (relating via its namesake to Spring).

The body resounds to the Goddess' touch, and the singer abandons their agency, relishing the sensation of being played by the divine musician. That different rāgas emanate from each cakra underlines their distinctive qualities. On the page, the lyric was set to Bhairavī rāginī, but it would be possible for the singer to work through the song and melodically incorporate each $r \overline{a g} a$ as it was named. The human body as a musical instrument was a popular image across repertoires of religious song (e.g. Cashin 1995, 236), but also, of course, recalls sangìta-śāstra, where the body is an instrument reverberating from nodes (sthāna) fixed within the $n \bar{a} d \bar{\imath} \mathrm{s}$. While a particular lineage or community might have a specific understanding of what that imagery entails, it is striking that, in this particular instance, Kailāscandra was thinking of "music readers" (sanigita pațhak), who might be familiar with classical music but uninitiated in the mysteries of the yogic body. For such readers, the musical vocabulary of this song, and mapping the work of the goddess over three octaves, would have been especially resonant (c.f. Lorea 2016, 218-9). Kailāscandra has reframed musicological ideas, embedding them in a śäkta worldview and then corroborating them through the works of English philosophers. This songbook is thus nostalgic in its archival impulse, but also self-consciously modern in its approach to the sonic body.

\section{Conclusion}

These examples from Bengali songbooks gesture to a larger conversation, across the nineteenth century, around how to apply music theory to religious practice and how to deploy 
the power of $r \bar{g} g a$ as a sonic technology. Print posed exciting possibilities for Bengali book entrepreneurs, patrons of Bengali literature, and religious communities: the example of Kailāscandra in particular demonstrates how urban śăkta societies were inspired by advances in the wider industry of musical publishing, and brought a systematic approach to the scattered archive of śākta gān. Besides collecting the lyrics, editors like Mādhābcandra Datta had engaged performers and musicians to discuss the performative qualities of texts, and how best to assign rāgas and tālas to prescribe modes of recital, singing, and worship. These conversations multiplied over the nineteenth century, and by the 1880s, when Kailāscandra assembled his own compilation, multiple readers, collectors, performers and poets were amending lyrics and prescribing rāgas.

We cannot reconstruct the decision-making process behind these editorials with any certainty, or make a definitive claim about the "logic" behind the $r \overline{a g} a$ allocations. These might, after all, have been whimsical, esoteric, or a matter of personal taste. However, they were neither random nor mechanically copied down from what was heard at a live performance: the editors took pride in considering different options, and discussing which setting was most appropriate with musicians. Examining these song collectors' interventions has several implications: it appears that the affective qualities and cultural associations- the dimensions of $r \overline{a g} a$ music discussed by connoisseurs and outlined in musicological literature-were taken into consideration, especially when a rāg $a$ was prescribed for a specific deity. These particular lyrics were not only scripts for worship, but instrumental in meditation and tantric visualisation techniques (dhyanna). Working from the muted, printed page, it is easy to neglect the auditory dimensions of the dhyanna, and how the appointed $r \bar{a} g a$ colours and nuances the experience of the deity.

Since we do not have access to the original music for these songs, we cannot know how a nineteenth-century musician would compose in rāgini Țoḍi in order to visualise the goddess Mātanigī. However, an editor like Kailāscandra, working in 1885, was curating songs over a hundred years after their composition, so was similarly distanced from the lyrics might originally have been performed. Perhaps it is the nostalgic tone of these later śâkta editors that explains the cultivation of melodic entities like rāmprasādi sur: a more or less fixed tune or stable style of singing for śākta lyrics, rather than an improvisation based on rāga music (c.f. Lorea 2016, 199-201). Prescribing a known tune instead of a rāga would narrow the singers' interpretative possibilities and also suggests a confessional readership that would know rāmprasāali musical repertoire.

Looking across the songbooks, rāga allocations continued to be a common choice for editors. Notably, some of the appointed raggas are quite uncommon, especially those hybrid rāgas that are almost unheard of today. It is possible that these reflect the preferences and repertoires of the consultant musicians: the individuals who favoured Bāgeśrīi-Kānora or Jhinjhotî-Lalit. This raises questions over how these songbooks were read and put into practice. After the editors' extensive work of assigning the rāgas, how many readers could actually perform them? Would all the readers of these texts have known the rāgas themselves, and be able to judge their appropriateness? Alternatively, would the more obscure rāga names have given the impression that the editor was an adept initiated in the esoterica of tantric singing?

Taken together, these different examples indicate how the editorial process encouraged musical reappraisals of literary and religious texts: framing a poem as a song lyric textured the verse with additional associations, and posed new possibilities in the context of worship and sonic visualisation. These editors drew on the formal dimensions of musical performance as well as the larger cultural signifiers encoded in the rāga's name. In a śäkta context, these were not merely aesthetic considerations, but were perhaps instrumental to worship and sādhana.

\section{References}


Bandyopādhyāy, N., Bhatțācārya, B.T. (1857) Śȳāmā Saìgīt, Calcutta: Barddhaman Maharajadhiraja Mahtabcand Bahadur.

Bhatkhande, V.N. 1984. Music Systems in India: A comparative study of some of the leading music systems of the 15th, 16th, 17th \& 18th centuries. Delhi: S. Lal.

Brown, K.R.B. 2003. Hindustani music in the time of Aurangzeb. Unpublished doctoral thesis. SOAS, University of London.

Bor, J. 1999. The Raga Guide: A survey of 74 Hindustani ragas. Rotterdam: Nimbus Records. Bühnemann, G. 2000. The Iconography of Hindu Tantric Deities. Groningen: E. Forsten Cashin, D. 1995. The Ocean of Love: Middle Bengali Sufi literature and the fakirs of Bengal. Stockholm: Association of Oriental Studies, Stockholm University.

Caudhurī, M.D. 1848. Sañgītānanda Laharī. Calcutta: Samacar Candrika.

Chatterjee, C. 1996. Śāstrîya Sañgìta and Music Culture of Bengal through the Ages. Delhi: Sharada Pub. House.

Das, R.P. 1992. Problematic aspects of the sexual rituals of the bauls of Bengal. Journal of the American Oriental Society, 112, 388-422.

Dās, R.S. 1818. Sañgītatarañga. Calcutta: Bangala Press.

Flood, G.D. 2005. The Tantric Body: the secret tradition of Hindu religion. London: I.B. Taurus.

Ganapathy, T.N. (ed.) 2013. The Tirumandiram. Quebec: Babaji's Kriya Yoga and Publications.

Gangoly, O.C. 1935. Rāgas and Rāginīs. New Delhi: Munshiram Manoharlal.

Ghoṣ, A. 1889. Sañgitasāgar. Calcutta: Panchanan Ghosh.

Hayes, G.A. 2003. Metaphoric Worlds and Yoga in the Vaiṣnava Sahajiyā Tantric Traditions of Medieval Bengal. In I. Whicher and D. Carpenter (eds.) Yoga: the Indian Tradition. London and New York: Routledge, pp. 162-184.

Imam, H.M.K. 1925. Ma'dan al-mūsīqī. Lucknow: Hindustani Press. English transl. (195960) Ma'dan al-mūsīqī: melody through the centuries, by G. Vidyarthi, Sangeet Natak Akademi Bulletin 11-12, 6-14, 13-26, 33, 49-58.

Kaufmann, W. 1968. The Ragas of North India, Bloomington, Ind.: The International Affairs Center.

Kinsley, D.R. 1997. Tantric Visions of the Divine Feminine: The Ten Mahāvidyās. Berkeley and Los Angeles: University of California Press.

Kitada, M. 2012. The Body of the Musician: an annotated translation and study of the Pindotpatti-prakarana of Śärnigadeva's Sañgītaratnākara. New York: Peter Lang.

Lath, M. 1995. The Body as an Instrument: a theoretical choice made by Śārngadeva. In B. Bäumer (ed.) The Ägamic Tradition in the Arts, New Delhi: IGNCA, pp. 101-113.

Leante, L. 2009. The Lotus and the Ling: imagery, gesture and meaning in a Hindustani $r \bar{a} g$. Ethnomusicology Forum, 18:2, 185-206.

Lorea, C.E. 2016. Folklore, Religion and the Songs of a Bengali Madman: a journey between performance and the politics of cultural representation. Leiden: Brill.

Māhtābcānd, Barddhamān Mahārājādhirāja Bāhadur. 1853. Sañgītabilās. Calcutta: P.S.D. Rosario \& Co.

Māhtābcānd, Barddhamān Mahārājādhirāja Bāhadur. 1880. Bhaktigānāmṛta, Bardhaman: Maharajadhiraja Aphtabcand Bahadur.

Māhtābcānd, Barddhamān Mahārājādhirāja Bāhadur. 1881. Sañgītasudhārkar, Part II. Bardhaman: Adhiraj Press.

Mallinson, J. and M. Singleton 2017. Roots of Yoga. London: Penguin Books.

McDermott, R.F. 2001a. Mother of my Heart, Daughter of my Dreams: Kālī and Umā in the Devotional Poetry of Bengal. New York: Oxford University Press.

McDermott, R.F. 2001b. Singing to the Goddess: Poems to Kāli and Umā from Bengal. New York: Oxford University Press.

McDermott, R.F. 2011. Revelry, Rivalry, and Longing for the Goddesses of Bengal: the fortunes of Hindu festivals. New York: Oxford University Press.

McLean, M. 1986. Devoted to the Goddess: the life and work of Ramprasad. Albany: State University of New York Press. 
Powers, H. 1980. Illustrated inventories of Indian rāgamālā painting. Journal of the American Oriental Society, 100:4, 473-493.

Rowell, L. 1992. Music and Musical Thought in early India. Chicago: University of Chicago Press.

Roy, B.K. 1969. The Career and Achievements of Maharaja Nanda Kumar, Dewan of Bengal (1705-1775). Calcutta: Punthi Pustak.

Schofield, K.B. 2018. Music, Art, and Power in Adil Shahi Bijapur, c.1570-1630. In K. Singh (ed.) The Arts of the Deccan, Mumbai: Marg, pp. 68-87.

Sharif, A. 1967. Madhyayuger Rāg-Tālnāmāa. Dhaka: Bangla Academy.

Sharma, P.L. 1995. Mahābhūtas in Sañgīta-Śāstra with special reference to Yoga and Āyurveda. In B. Bäumer (ed.) The Āgamic Tradition in the Arts. New Delhi: IGNCA, pp. 87-100.

Shin, J.E. 2018. Change, Continuity and Complexity: The Mahāvidyās in East Indian Śākta Traditions. London: Routledge.

Shringy, R.K. (trans.) 1978. Sañgīta-Ratnākara of Śārñgadeva. Varanasi: Motilal Banarsidass.

Stephen, J. 1885. The Story of Nuncomar and the Impeachment of Sir Elijah Impey. London: Macmillan and Co.

Simha, K. 1885. Sādhak Saìgīt. Calcutta: Victoria Press.

Singh, S. 1990. Surataranga, Jodhpur: Rajasthana Pracyavidya Pratisthana.

Te Nijenhuis, E. 1977. Musicological Literature. Wiesbaden: Harrassowitz.

Te Nijenhuis, E., and F.N. Delvoye 2010. Sanskrit and Indo-Persian Literature on Music. In J. Bor et al. (eds.) Hindustani Music: Thirteenth to Twentieth Centuries. New Delhi: Manohar, pp. 35-64.

Urban, H.B. 2001. The Economics of Ecstasy: Tantra, Secrecy, and Power in Colonial Bengal. Oxford: Oxford University Press.

Vasudeva, S. 2004. The Yoga of the Mālinivijayottaratantra. Pondicherry: Institut français de Pondichéry.

White, D.G. 2003. Yoga in early Hindu Tantra. In I. Whicher and D. Carpenter (eds.), Yoga: the Indian Tradition. London and New York: Routledge, pp. 143-161.

Wilke, A. and O. Moebus 2011. Sound and Communication: An Aesthetic Cultural History of Sanskrit Hinduism. Berlin: De Gruyter.

Williams, R.D. 2016. Music, Lyrics, and the Bengali Book: Hindustani musicology in Calcutta, 1818-1905. Music and Letters, 97:3, 465-495.

\footnotetext{
${ }^{\mathrm{i}}$ I would like to thank Katherine Schofield, Megan Robb, Richard Widdess, James Mallinson, and Joel Bordeaux for their comments while preparing this article, as well as the two anonymous readers who gave me extremely helpful notes during the review process.

ii For earlier, pre-print musicological works in Bengali see Sharif 1967; Chatterjee 1996.

iii The seven notes are frequently associated with particular cakras in ritual, e.g. Lorea 2016, 219.

iv e.g. the Brajbhasha Surataranga (1748) v.27, see Singh (1990).

${ }^{v}$ i.e. reality as conditioned by the three qualities (gunas).

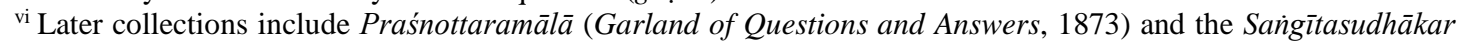
(Moon of Music, Part I 1876, Part II posthumously 1881).

vii i.e. when the notes are not performed in a "straight” sequence, e.g. Sa-Ma-Ga-Pa, rather than Sa-Ga-Ma-Pa.

viii E.g. colour lithograph of the Mahāvidyās, printed in Calcutta c.1895 (British Museum, number 2003,1022,0.37).

${ }^{i x}$ In this alternative scheme, Chinnamastā was assigned Lagni Bhairabī instead.

x There is a Bāgeśrī Kānaḍā in the current Hindustani repertoire, and Aḍānā is one of the main Kānaḍa rāgas.

${ }^{x i}$ Kailāscandra assigned Bāgeśrī to Kālī, Jhinjhhoțī to Tārā, Behāg to Rajrajeśvarī, Bahār to Bhubaneśvarī, Bhairavī to Bhairavī, Lagni Bhairavī to Chinnamastā, Paraj to Dhāmāvatī, Kedār to Baglā, Jayjayantī to Mātañgī, and Multān to Kamlā.

xii Nandakumār Rāy is remembered for his court case against Warren Hastings. See James (1885); McDermott 2001a, 132; Roy (1969).

xiii Translation adapted from McDermott 2001a, 240-241.

${ }^{\text {xiv }}$ Referring to the three $n \bar{a} d \bar{\imath} \mathrm{s}$, or energy channels in the yogic body (iḍa, pingala, sușumnāa) and equating them to the three strings of the instrument.

${ }^{x v}$ Literally "heron-headed”, kānki mukhe. Herons may colloquially be associated with ostentatious or superficial religious behaviour.
} 